\title{
Analysis of Indonesian Islamic and Conventional Banking Before and After 2008
}

\author{
Arfianti Novita Anwar ${ }^{1}$ \\ ${ }^{1}$ School of Business Pelita Indonesia Pekanbaru, Indonesia \\ Correspondence: Priyono, Post Graduate Management Program, University of Bina Darma Palembang, Indonesia. \\ E-mail: priyono.unu_sidoarjo@yahoo.com
}

Received: September 19, 2016

Accepted: October 13, $2016 \quad$ Online Published: October 25, 2016

doi:10.5539/ijef.v8n11p193

URL: http://dx.doi.org/10.5539/ijef.v8n11p193

\begin{abstract}
This study aims to analyze the performance of Islamic banks and conventional banks before and after the implementation of Islamic Banking Act 2008. The performance will be measured using CAMEL ratio selected. This research is considered essential in examining the positive contribution of the application of the Act to improve the performance of Islamic banks in Indonesia. By using secondary data, this study compared the performance of Islamic banks with that conventional bank selected as samples during the study period. Data were analyzed using the Wilcoxon Signed Rank Test for inter-temporal and Mann-Whitney test for inter-bank. Inter-temporal Tests conducted on Islamic Banking showed that a significant difference was only seen in the NPF ratio of 2 years before and after implementation of Islamic Banking Act. As for conventional banks showed a more diverse ie for 1 year before and after the application of the Law on Islamic Banking there are significant differences for the ROA and ROE, two years before and after implementation of the Law Islamic banking there are significant differences for the CAR, ROA, ROE and NIM and for the overall test a significant difference to CAR, ROA, ROE, NIM and efficiency. Inter-bank testing showed that prior to the application of Islamic Banking Act there are significant differences between conventional banks and Islamic banks to CAR, ROA and efficiency. Furthermore, after the application of Islamic Banking Act there is a significant difference for the CAR and LDR / FDR.
\end{abstract}

Keywords: CAMEL ratios, Islamic bank, conventional bank, Indonesia Islamic bank act

\section{Introduction}

The idea to hold Islamic Banking in Indonesia is already developed since 1970. But it was realized in 1992 after deadlock for more than 20 years. Islamic banking in Indonesia has to face the regulations problem as government did not prepare the comprehensive regulation to run Islamic Banking business. Muamalat is the first Islamic Bank in Indonesia that was held only based on Indonesia Banking Act No. 7 in 1992 and Goverment Rules No. 72 in 1992.

Comparing to Malaysia, the government prepared comprehensive regulation for Islamic Banking since 1983. It is noted for Indonesian Government as regulator which stated the regulation in 2008 (as Known as Islamic Banking Act).

Indonesian Islamic Banking Act stated as response for the critics and barrriers faced by islamic banking to develop and compete with conventional banking.

Islamic banking is not developed as good as conventional banking during 1992 to 1997. Siregar (2002) wrote "the regulations existence is the core problems to be solved in the short term as it is the criteria for islamic banking operation in Indonesia". Later on Rivai (2010) argued that Indonesia Islamic Banking developing is not equal from conventional banking since the regulations of Islamic banking is not prepared the good condition to develop well".

The implementation of Banking Act No. 10 in 1998 to change Banking Act No. 7 in 1992 began preparing better condition to Islamic banking movements. This regulations is strengthen by The Act No. 23 in 1999 which is give the authority to conventional bank to run the business based on shariah principle.

January 24, 2004 Indonesian Islamic Banking had another positive stimulus to the issuance of the decision Indonesian Council of Ulama (MUI) No. 1 of 2004 on Interest which decided that the Interest practice by 
conventional banks at the moment have met the criteria of usury that occurred at the time of the Prophet Muhammad.

The growth of Islamic Bank after the announcement from the institutional side is more encouraging. After the MUI fatwa was announced, until the end of 2004 obtained statistical data of Islamic banking that says that there are 3 Islamic Banking (coupled with Mega Indonesia Islamic Banking), 15 Islamic Unit (coupled with DKI Bank, Riau Bank, South Kalimantan Bank, Niaga Bank, North Sumatra Bank, Aceh Bank, and Permata Bank), and 88 Rural Banks (Bank Indonesia, 2005).

Growth in the number of branch network is accompanied by the growth of assets. Continuous growth can be maintained in Islamic banking. By the end of 2004 the growth of the asset until 9,19\%. This growth is the second largest percentage in January 2004 after the Islamic banking is able to achieve asset growth of $11,44 \%$ from 2003.

However, growth has been achieved by Islamic Banking it is still not able to meet the target set in the Indonesian Banking Blueprint. Rivai (2010) revealed that Act No. 10 of 1998 has not been done up to that market segment that can be achieved by Islamic banks are still far from the expectations set in the "Blueprint for Development of Indonesian Islamic Banking". Supposedly Islamic banks and conventional banks have a different character, the market share of conventional banks and Islamic banks are balanced (50:50).

Various groups argue that Islamic Banking growth rate is not optimal is triggered by the situation that the regulations of Islamic Banking is not specifically regulated in a legislation separate from conventional banking. Following encouragement and demands from many parties, the government finally approved the Law No. 21 of 2008 concerning Islamic Banking. Regulations which have been long expected by the businessman of Islamic banking of course gives impact to the growth of Islamic banking in Indonesia.

At the end of 2008 obtained the data noted as follows: five (5) Islamic Banking with its number of operating as many as 576 offices, 27 Islamic Unit by the number of offices that operate 214 offices, and 131 Rural Banks with its number of operating as many as 202 office. Growth is simply fantastic network of offices compared to previous years. The growth in the number is increasing significantly by the end of 2010 that there were 11 Islamic Banks with 1,215 offices, 23 Islamic Unit with 262 offices, and 150 Rural Banks With 286 office.

Asset growth continues to accompany the increase of operating the office network. From the data released by Bank Indonesia in 2010, the biggest asset growth occurred in 2010, from. 66.090 billion in 2009 to 97.519 billion.

Various phenomena and developments then are being interesting to study. For the optimistic view that the Islamic Banking Act will address the challenges and expectations of the stakeholders ahead, but not a few people who are pessimistic that this law will be able to bring Islamic banks become the majority choice than conventional banking.

According to Siti Fajriyah, one of Deputy Governor of Bank Indonesia, the number of Islamic bank customers at this time (position in 2008) is only about 3 million, whereas the number of Muslims is a potential to become customers of Islamic banks is more than 100 million people. The number of Muslims in Indonesia in 2010 has increased twofold to reach the 208 million. Thus, the majority of Muslims have not been associated with Islamic banks.

It is of course a tough challenge for Islamic banks in Indonesia. Although each bank has its particularity, but Islamic banks can't deny that much of conventional bank first developed in Indonesia. It is of course greatly affects the level of public confidence in the performance of Islamic banks.

However measure the performance of Islamic banks or conventional banks is not only seen from the quantitative growth of the office network only. Bank Indonesia establishes a mechanism for performance assessment comprehensive banking by considering various indicators include capital, asset quality, quality management, earnings, liquidity and Sensitivity to market risk. Indicators known as CAMELS terminology shows the performance of Islamic banks is the reference for the public to decide whether the presence of Islamic banks could actually be an alternative solution for them.

\section{Theoritical Framework, and Hypothesis}

Business banking is a form of business entity that is quite specific. Assessing the performance of the bank will always refer to the factors that are related to the level of health, in other words the bank's performance can be evaluated from the soundness of the bank concerned. The rating includes the financial aspect and non-financial aspects. 
Bank Indonesia as the bank responsible for managing and overseeing the overall banking activities establishes an approach or method to measure performance by using CAMELS method. This method has a lot of aspects that affect the financial condition of banks that can reflect real condition of a bank in the present and in the future.

For conventional banks, the rating system is done in accordance with Bank Indonesia Regulation No. 6/10/PBI/2004 which was published in gazetted on April 12, 2004. In Circular No. 6/23/DPNP dated May 31, 2004 and then arranged that the ratings of the bank include an assessment of the CAMELS factors which include Capital, Asset Quality, Management, Profitability, Liquidity, and Sensitivity to market risk.

For Islamic banks, the rating stipulated in Bank Indonesia Regulation No. 9/1/PBI/2007 concerning the Rating System for Commercial Banks based on Sharia principles, the soundness of banking is defined as the result of qualitative assessments of various aspects affecting the condition or performance of a bank or Sharia through: (a) the assessment of quantitative and qualitative assessment of factors of capital, asset quality, earnings, liquidity, sensitivity to market risk, and (b) a qualitative assessment of management factors.

In this study, the performance assessment is limited to the four aspects of assessment namely capital, asset quality, profitability and liquidity. Selection of the ratios used are based on the reference matrix computation or analysis CAMELS issued by Bank Indonesia.

\subsection{Capital}

Capital aspect carried out by measuring the position of Capital Adequacy Ratio (CAR). In some studies CAR ratio is equated with the ratio of Capital to Risk Assets Ratio (CRAR). Capital adequacy ratio is the ratio between capital to risk weighted assets, in other words as well known as the Minimum Capital Requirement. The higher this ratio means that the bank has adequate capital as supporting risky assets so that the possibility of a bank in unhealthy conditions getting smaller. According to Bank Indonesia regulation, the minimum value for the CAR of commercial banks is $8 \%$.

This ratio can be formulated as follow:

$$
\text { CAR }=\frac{\text { Capital }}{\text { Risk }- \text { Weighted Assets }} \times 100 \%
$$

\subsection{Asset Quality}

Productive assets or often also called earning assets are all assets owned by banks with a purpose to be able to earn income in accordance with its function. Measurement of productive assets can be done by measuring a bank's non-performing loans. Non-performing loans are loans that do not stay on schedule so that the installment of arrears. Loans included in NPL category is substandard loans, doubtful loans and loss. High level of NPL ratio will cause difficulties at once diminishes the bank concerned. Thus the bank is required to be able to maintain credit to always be in a reasonable rate that is $3-5 \%$ of total loans. This is in accordance with the best commercial banks NPL standards set by Bank Indonesia at below 5\%.

\subsection{Earning}

Rate of return is used to measure the bank's ability to improve profitability, measuring the level of business efficiency and profitability achieved. Earning not only refers to the quantity and profitability trends, but also the factors that affect the availability and quality of earnings itself. It is used for profitability aspect ratios Return on Assets (ROA), Return on Equity (ROE), Operational Efficiency Ratio and Net Interest Margin (NIM).

ROA ratio is used to measure the ability of the bank's management in obtaining the profit generated from the average total assets of the bank concerned. In some studies, ROA is mentioned in terms of Return on Average Assets (ROAA). The higher this ratio, the greater the level of profit achieved by the bank so that the possibility of the bank to be unhealthy would be diminished. Standard according to Bank Indonesia ROA was $1.5 \%$.

This ratio can be formulated as follows:

$$
R O A=\frac{\text { Earning Before Tax }}{\text { Average of Productive }} \times 100 \%
$$

Here ROE shows the bank's ability to obtain a net benefit associated with the payment of dividends. In some studies this ratio is called the Return on Average Equity (ROAE). The greater this ratio the greater the increase in net profit of the bank which will further raise the price of bank stocks and the greater the dividends to be received by investors. Standard ROE according to Bank Indonesia is $12 \%$.

ROE can be formulated as follows: 


$$
\text { ROE }=\frac{\text { Net Profit }}{\text { Equity }} \times 100 \%
$$

NIM is the net interest income compared to average earning assets. In some studies NIM is expressed by the term Net Income Margin Financing (NFIM). For lack of interest, the Islamic Banking NIM ratio is known as Net Operating Margin (NOM).

The net interest income can be derived by subtracting interest income earned by the interest expense to be incurred. To increase the ratio of NIM, the banks need to reduce the cost of the interest to be paid by banks to each source of funds is concerned.

NIM can be formulated as follows:

$$
\text { NIM }=\frac{\text { Net Interest Income }}{\text { Average of Productive Assets }} \times 100 \%
$$

Operational efficiency ratio is obtained by comparing Operating costs compared to operating income. This ratio is used to measure the ratio of operating costs or the costs of intermediation to the operating revenue of the bank. The higher this ratio means the more inefficient the operational costs incurred by the bank concerned so that the possibility of a bank in the greater unsanitary conditions. Standard best BOPO according to Bank Indonesia is $92 \%$.

This ratio is defined as follows:

$$
\text { BOPO }=\frac{\text { Operational Expenses }}{\text { Operational Income }} \times 100 \%
$$

\subsection{Liquidity}

Liquidity is used for measuring the ability of company to fullfil their current liability (Halim, 2007). Liquidity indicates the availability of funds and sources of funds in the present and future. A bank is said to be liquid if the bank is able to pay all of its debts, particularly short-term debts. In addition the bank also must be able to meet all requests for loans worth financing.

From the assets side, liquidity is the ability to change all of the assets into cash. Meanwhile, from the point of liabilities, liquidity is the bank's ability to meet the funding requirements through increased liability portfolio.

In this study, the liquidity ratio is represented by the variable Loan to Deposit Ratio (LDR). It can be concluded that the measurement of the LDR will be concerned with two things: the profitability and liquidity of a bank. Banks that have a low level of LDR, have better liquidity. This is due to the Third Party Funds raised from the public are not entirely allocated for the purpose of credit. Funds have been allocated to credit (loan) is the most illiquid assets, which can only be cashed at maturity. But on the other hand a low LDR shows that bank productivity is also low. This is due to the realization of bank intermediation role in channeling back in third party funds collected from the community for the benefit of investment in the real sector.

LDR best standard by Indonesian banks is $85 \%-100 \%$. If a bank has a LDR of $100 \%$ is still considered good if the capital adequacy ratio at least $14 \%$. This means expansion undertaken by these banks was financed by capital owners. It can be concluded that the higher the LDR, the bank is said to be more productive, the records must be accompanied by CAR were also good.

This ratio is defined as follows:

$$
L D R=\frac{\text { Total Lending }}{\text { Third fund Parties }} \times 100 \%
$$

\section{Research Methods}

The object of this research is Islamic Banks and Conventional Banks recorded in the Directory of Bank Indonesia during the period 2006 to 2010. The Islamic Bank referred to in this research are Islamic Banks that issue financial statements as an independent banking entity. While the Conventional Bank is a Conventional Commercial Bank also issued financial statements independently.

This study uses secondary data that is accessed from a variety of sources. Among others: Bank Indonesia website, the website of each bank will be the study sample, as well as websites that are considered important and bonafide to obtain the necessary data. They will also be conducted library research to collect the data deemed necessary.

The data analysis method to be used is the quantitative Statistical analysis using SPSS and EXCEL software. In connection with the research data that is classified as a small sample, it will be used non-parametric statistical 
tests, to anticipate the data abnormalities that may occur. For hypothesis testing will be conducted comparative testing is to test the parameters that have been set on each object to be tested statistically using different test non-parametric Wilcoxon Signed Rank Test for inter-temporal test and Mann Whitney Test to test inter bank

\section{Data Analysis and Discussion}

Table 1. Summary of Islamic banking wilcoxon signed ranks test

\begin{tabular}{llcccccc}
\hline Bank & Variable & 1 Year t Test & Conclusion & 2 Years t Test & Conclusion & Overall Test & Conclusion \\
\hline & CAR & 0.686 & Not Significan & 0.225 & Not Significan & 0.445 & Not Significan \\
& NPF & 0.893 & Not Significan & $0.08^{*}$ & Significan & 0.203 & Not Significan \\
& ROA & 0.225 & Not Significan & 0.893 & Not Significan & 0.445 & Not Significan \\
Islamic Banks & ROE & 0.138 & Not Significan & 0.686 & Not Significan & 0.959 & Not Significan \\
& NOM & 0.345 & Not Significan & 0.345 & Not Significan & 0.169 & Not Significan \\
& Eff & 0.686 & Not Significan & 0.345 & Not Significan & 0.799 & Not Significan \\
& FDR & 0.5 & Not Significan & 0.893 & Not Significan & 0.445 & Not Significan \\
\hline
\end{tabular}

$* \alpha: 10 \%$.

Source: Research, 2013.

Inter temporal testing is used on this research on Islamic Banking for examining the difference of bank's performance one year before-after 2008, two years before-after 2008 and overall testing. The result shows that the NPF of Islamic Banking significantly different two year before and after the implementation of Islamic Banking Act.

Table 2. Summary of conventional banking Wilcoxon signed ranks test

\begin{tabular}{llcccccc}
\hline Bank & Variabel & 1 Year t Test & Kesimpulan & Uji beda 2 tahun & Kesimpulan & Keseluruhan & Kesimpulan \\
\hline & CAR & 0.5 & tidak signifikan & 0.043 & signifikan & 0.009 & signifikan \\
& NPL & 0.5 & tidak signifikan & 0.5 & tidak signifikan & 0.508 & tidak signifikan \\
& ROA & 0.043 & signifikan & 0.043 & signifikan & 0.005 & signifikan \\
Konvensional & ROE & 0.043 & signifikan & 0.043 & signifikan & 0.005 & signifikan \\
& NIM & 0.225 & tidak signifikan & 0.043 & signifikan & 0.007 & signifikan \\
& BOPO & 0.5 & tidak signifikan & 0.225 & tidak signifikan & 0.093 & tidak signifikan \\
& LDR & 0.893 & tidak signifikan & 0.225 & tidak signifikan & 0.139 & tidak signifikan \\
\hline
\end{tabular}

$* \alpha: 10 \%$.

Source: Research, 2013.

Inter temporal testing is done for conventional banks as well as Islamic Banks. The result shows that CAR of conventional banks differ significantly for two years and overall test.

Similar results were also aimed at testing the NIM. Tests on ROA and ROE show a significant difference for tests performed one year, two years before and after 2008, as well as the overall test. Efficiency ratio shows difference only for overall test. In contrast, testing for NPL and LDR did not show any significant differences both tests one year or two years before and after 2008, as well as the overall testing.

Table 3. Summary of Mann-Whitney test

\begin{tabular}{ccccc}
\hline Variable & Before & Conclusion & After & Conclusion \\
\hline CAR & 0.034 & Significant & $0.052^{*}$ & Significant \\
NPF/NPL & 0.597 & Not Significant & 0.29 & Not Significant \\
ROA & 0.028 & Significant & 0.112 & Not Significant \\
ROE & 0.762 & Not Significant & 0.545 & Not Significant \\
NOM/NIM & 0.88 & Not Significant & 0.162 & Not Significant \\
Efficiency & 0.008 & Significant & 0.226 & Not Significant \\
FDR/LDR & 0.762 & Not Significant & $0.096^{*}$ & Significant \\
\hline
\end{tabular}

$* \alpha: 10 \%$

Source: Research, 2013. 
Interbank testing performed by using Mann Whitney test showed that the CAR of Islamic banks before and after 2008 is significantly different when compared with conventional banks. CAR of conventional banks recorded better than Islamic banks. For NPF/NPL, ROE and NOM/NIM the performance of Islamic banks do not differ significantly from conventional banks both before and after 2008. Thus, ROA Islamic banks shows significant different before 2008, but has none after 2008. Then, the test of FDR/LDR shows that before 2008 the banks unsignificantly different but after 2008 the banks show significant difference.

From each of ratios used in the study can be stated that the implementation of Islamic Banking Act 2008 is able to align the performance of Islamic Banks and Conventional Banks for several ratios are ROA and Efficiency.

As for the ratio of NPF/NPL, ROE, and NOM/NIM Islamic banks have not shown improvement. It can be analyzed further by re-look at various situations and phenomena both with regard to the law, as well as other factors.

Implementation of Law No. 21 about the Islamic banking coincided with a crisis period which of course affects the banking business such beliefs. Islamic Banks claimed to have resilience in crisis situations. Post-crisis proved that the Islamic Bank was able to record an increasing of NPL, ROE, NIM, ROA and LDR. However, from the facts obtained in this study, nonetheless for these indicators Islamic Bank suffered a setback as the excess of the European crisis that occurred in 2008 was that the CAR and ROA. When compared with the conditions of a Conventional Bank suffered a setback in the CAR, NPLs, ROA, ROE, NIM and ROA. Conventional banks are only able to record an increasing in the LDR.

Nevertheless, the setbacks experienced by Islamic banks in the CAR and ROA also experienced by conventional banks. The decline in the performance of conventional banks worse on these ratios, which in turn can align the performance between Islamic banks and conventional banks.

To measure the performance of which has not been able to rise, following a variety of other situations. For example, although they apply a revenue sharing system, but it is undeniable that the current price (read: revenue sharing) financing Islamic Banking in Indonesia is higher than the price (read: interest) loans set by the Bank Conventional (Infobank, 2011). This implicates the difficulty of developing a market share of Islamic banks that have been targeted.

Furthermore, if the terms of the content of Law No. 21 of the Islamic banking in 2008, it can be stated that the bill is also not so capable of supporting the performance of Islamic Banking. For example, when the law states that the Sharia Bank should be able to improve and/or maintain the Bank, Islamic Bank must return refers to the guidelines or criteria for Rating Bank issued by Bank Indonesia in 2007, before the Islamic Banking Act set. It becomes contradictory, wherein, consideration of the application of Sharia Banking Act conducted to answer a variety of things those are still not supportive nature of business of the Islamic Bank, but after the law was successfully applied, the questions still unanswered.

These circumstances are the obstacles still to be faced by the Islamic Bank to compete with conventional banks. Of course, also can not be denied that the existence of Islamic Banking is still relatively new when compared to conventional banks are also the cause of Islamic Bank's inability not to compete with the existence of the Conventional Banks.

\section{Conclusions}

Based on the description, analysis, and discussion that has been described, it can be concluded as follows:

1) Islamic Banking Act No. 21 Year 2008 that is expected to stimulate the performance of Islamic Banks in Indonesia. in the fact had not shown the improvement yet.

a) This is evidenced by the absence of differences in performance before and after the period of application of the Islamic Banking Act as measured by the ratio of CAR, ROA, ROE, NIM, ROA and LDR (inter-temporal comparisons). However, There is a significant difference of NPF before and after two year of implementation of Islamic Banking Act.

2) In the Conventional Bank, there is a difference in performance for some ratios are CAR, ROA, ROE and NIM before the period of 2008 to after a period of 2008. The ratio of CAR, ROA, ROE and NIM before the period of 2008 was better than after a period of 2008. This is the impact of the crisis coincided with the implementation of Islamic Banking Act 2008. Meanwhile others, namely NPL, ROA and LDR did not differ significantly throughout the study period (inter-temporal comparisons).

3) There are some differences in performance between Islamic Banks and Conventional Banks before 2008 (i.e the ratio of CAR, ROA and Efficiency, which conventional banks recorded better than Islamic bank), 
but after the implementation of the Islamic Banking Act ROA and Efficiency between islamic banks and conventional banks balance. This shows that the Islamic Banking Act that has been applied contributes to improve the performance of Islamic banks in the ROA and Efficiency when compared with the same performance ratio in conventional banks (inter-bank testing).

Based on the conclusions obtained then the regulator should really prepare other tools to support the Law No. 21 on Islamic Banking, so as to respond with comprehensive rules of Islamic Bank which still refers to the rules of natural Conventional Bank of different business with Bank Islam.

From the research that shows that Islamic banks showed increased performance in ROA and Efficiency. Islamic banks should continue to improve its efficiency in boost performance, for example by looking for opportunities for low cost funds, such as Islamic banks more actively looking for opportunities to manage government funds.

For subsequent studies, are expected to cover the limitations of the study, both in terms of the period, the number of samples, as well as on the scope of the variables to be analyzed.

\section{References}

Bank Indonesia. (2002). Blueprint of Development of Indonesian Islamic Banking. Retrieved from http://www.bi.go.id/id/ruang-media/siaran-pers/Documents/cetakbirups.pdf

Bank Indonesia. (2011). Indonesian Islamic Banking Outlook 2011. Retrieved from http://www.bi.go.id/id/publikasi/lain/lainnya/Documents/2c1641942a164cde90824ac546416c5dOutlookPer bankanSyariah2011.pdf

Bank Indonesia. (2012). Indonesian Islamic Banking Outlook 2012. Retrieved from http://www.bi.go.id/id/publikasi/lain/lainnya/Documents/a09a6dcb151c4916bc6447ef2ec785fcoutlook_per bankan_syariah_2012.pdf

Ismal, R. (2011). Islamic Banking in Indonesia: Lesson Learned. Directorate of Islamic Banking- Bank 2011 Retrieved

from http://unctad.org/sections/wcmu/docs/cImem3_3rd_Country_Paper_Indonesia.pdf

Rivai, V., \& Arviyan, A. (2010). Islamic Banking, Islamic Bank System Not Only Solution Crisis And Solutions In the face of Various Issues Banking and Global Economy: A Theory, Concepts and Applications, Earth Literacy, 2010.

Siregar, M. E. (2002). Sharia Banking Development Agenda to Promote Healthy Economic System in Indonesia: Evaluation, Prospects and Policy Direction. Iqtisad Journal of Islamic, 8(1). Retrieved from http://journal.uii.ac.id/index.php/Iqtisad/article/view/360/275

Siregar, M. E. (2011). Recent Development of Islamic Banking in Indonesia. Directorate Islamic Banking - Bank Indonesia, 2011. Retrieved from http://www.bi.go.id

Statistics Islamic Banking. (2005). Bank Indonesia, Jakarta, 2005.

Statistics Islamic Banking. (2006). Bank Indonesia, Jakarta, 2006.

Statistics Islamic Banking. (2008). Bank Indonesia, Jakarta, 2008.

Statistics Islamic Banking. (2009). Bank Indonesia, Jakarta, 2010.

Statistics Islamic Banking. (2010). Bank Indonesia, Jakarta, 2010.

\section{Copyrights}

Copyright for this article is retained by the author(s), with first publication rights granted to the journal.

This is an open-access article distributed under the terms and conditions of the Creative Commons Attribution license (http://creativecommons.org/licenses/by/4.0/). 